\title{
Tourism Development in Mountainous Regions, Social Structure's Point of View; Advantages and Disadvantages, Erzurum/Turkey Case Area
}

\author{
Dağlık Alanların Turizm ile Gelişiminde Sosyal Yapıdan Kaynaklanan \\ Avantajlar ve Dezavantajlar; Erzurum/Türkiye Örnek Alanı
}

\author{
Nilüfer GÜRER \\ Gazi University, Faculty of Architecture, Department of City and Regional Planning, Ankara, Turkey
}

\begin{abstract}
Mountainous regions have a global importance with their potentials like difficult topography, changing climate, biological, cultural and ethnical diversities, unique landscape values. However, despite to all the positive qualities, mountainous areas are less developed in many parts of the world due to some limitations caused by above listed values. There are too many researches done on how the sustainable development, particularly in mountainous areas can be realized, and different development models for mountainous areas are proposed. Tourism based development models are one of the most preferable development methods for the mountainous areas because of their characteristics. The social structure of the society is also an important component for the development in any situation and for every type of development model. For this reason this paper will try to analyze the effects of social qualities with both positive and negative effects. After a brief theoretical introduction of the topic, and a short description of the case area, the social indicators of sustainable tourism will be discussed. The indicators which are directly related with the social structure of the local society, like gender distribution, age pattern, education level are measured with questionnaires in Erzurum case study area for tourism sector. The observational results which are getting by interviews are also discussed. In conclusion, based on the results obtained, in development of mountainous areas the advantages and disadvantages, due to the social structure, will be discussed and practical suggestions will be evaluated.
\end{abstract}

Key words: Sustainable tourism development, mountainous regions, social indicators, Erzurum, Turkey.

Özet: Dağlık alanlar, sahip oldukları potansiyeller sebebi ile (topografik yapıları, iklim yapıları, biyolojik, kültürel ve etnik çeşitlilikleri, eşsiz peyzaj nitelikleri vb.) küresel ölçekte önemli bir yere sahiptir. Ancak tüm bu pozitif niteliklerinin yanı sıra, sahip oldukları niteliklerden kaynaklanan kısıtlllıklar sebebi ile, dünyanın pek çok bölgesinde az gelişmiş alanlar arasında yer almaktadırlar. Dağllk alanlar özelinde, sürdürülebilir kalkınmanın ne şekilde sağlanabileceği konusunda Dünyada pek çok araştırma yapılmakta, bu alanların kalkınmasına ilişkin farklı modeller geliştirilmektedir. Dağllk alanlar için, sahip oldukları nitelikler de göz önünde bulundurulduğunda, turizm temelli kalkınma modelleri en çok tercih edilen modeller olarak öne çıkmaktadır. Hangi tür kalkınma modeli tercih edilirse edilsin, toplumların sosyal yapıları kalkınmada en önemli bileşenlerden birisidir. Bu nedenle, makale kapsaminda yerel toplumların sosyal niteliklerinin, sürdürülebilir kalkınmadaki pozitif ve negatif etkileri analiz edilmeye çalışılmıştır. Konuya ilişsin kısa bir teorik girişin ardından çalışma alanı genel özellikleri ile tanımlanmış, üçüncü bölümde ise sürdürülebilir turizmin sosyal göstergeleri tartışılmıştır. Aynı bölümde, yerel toplumun sosyal yapısını tespit etmeye yönelik gerekli veriler (nüfusun cinsiyet dağıllmı, yaş dăğlımı, eğitim seviyesi vb.) ve çalışma alanı için belirlenen sürdürülebilir turizmin sosyal göstergeleri arazi çalışmaları ve anket yöntemleri ile ölçülmüş, elde edilen veriler, arazi gözlemleri ve sözlü görü̈şmeler de değerlendirilerek tartışılmıştır. Sonuç bölümünde, elde edilen verilere dayanılarak, dağlık alanların kalkınmasında, yerel toplumun sosyal yapısından kaynaklanan avantajlar ve dezavantajlar tartışılarak, uygulamaya yönelik pratik öneriler geliştirilemeye çalışılmıştır. Anahtar sözcükler: Sürdürülebilir turizm gelişimi, dağllk alanlar, sosyal göstergeler, Erzurum, Türkiye. 


\section{Sustainable Tourism Development and Mountainous Areas}

The subject of "mountainous regions sustainability" was taken into consideration for the first time in 1992, with the chapter 13 of Agenda 21 (Price and Kim, 1999). The year of 2002 was crowned as the "international year of mountains" and more attention has been paid to mountain societies. Approximately $10 \%$ of world population earns their livings through mountain resources (Price and Kim, 1999; Price, 2002, Price et al., 2004, Funnell and Parish, 2001). The sources gained and the services taken from these areas are believed to be important for the half of the world population (Price and Kim, 1999, Ives, 1992).

Mountainous areas are wealthy and important regions of the world from the points of their flora, fauna and cultural diversity, water, minerals and energy resources, forest and agricultural products, and recreational opportunities (Dax, 2002; Denniston, 1996; Euromontana, 2004; Funnell and Parish, 2001; Messerli and Ives; 1997; Mountain Institute, 1999; Nepal, 2002; Price, 2002; Price and Kim; 1999; Price et al., 2004). The existence of natural values and resources act as driving forces for social and economic development processes, and they are added value for the sustainability of these resources with their positive outputs (Somuncu and Inci, 2004). As a result of rapid population growth, lack of suitable transportation systems and poor social infrastructure (education, health and services) the natural and cultural heritage is influenced negatively (Mountain Agenda, 1997; Price et al., 2004).

In many parts of the world, tourism initiatives which use natural resources (like eco-tourism, mountain tourism, rural tourism etc.) are valued for creating job and infrastructure opportunities, solving problems and decreasing negative environmental effects for local development (Briquel, 2006; Heberlein et al., 2002; Kruk et al., 2007; Mountain Agenda, 1997; Nepal, 2002; Price, 2002; Rogerson, 2002) and mountains provide different activities for people, who love impressive landscape, want to experience special lifestyles, traditions, besides they create land for peace and different sportive activities.

For achieving the tourism sustainability in ecologically sensitive areas, visitor satisfaction, awareness of the benefits for the local people and environmental protection policies must be integrated.

Tourism has two-sided effects, on one side it has positive impacts like creating different job and income opportunities, on the other side it has negative impacts such as social and environmental degradation. It is important to be aware of possible negative impacts while getting positive earnings (Pickering et. al., 2003; Price, 2002).

\section{Case Study Area; Erzurum Mountainous Region}

Erzurum is a province of Turkey, in the Eastern Anatolia Region of the country. The surface area of the Erzurum province is $25.323 \mathrm{~km}^{2}$ and it is the fourth biggest province in Turkey. The majority of the province is its elevated. Erzurum region has high mountain ranges extending in eastwest direction, plateaus, pastures, both surface and ground water resources, diversity of flora and fauna. The altitude of the province is $1950 \mathrm{~m}$. Most plateaus are about 2,000 m $(6,500 \mathrm{ft})$ above sea level, and the mountainous regions beyond the plateaus are 3,000 $\mathrm{m}(9,800 \mathrm{ft})$ and higher. In addition to these already existing natural values, the region had been hosting several civilizations in history. These merits make the cultural diversity richer. The region has high potential for the development of sustainable tourism with its natural, cultural, archeological richness and diversity (Gürer, 2010).

The population of the province is approximately 785000 people (1.11\% of Turkey) according to 2007 census of population. $62 \%$ of the population lives in the urban area and $38 \%$ lives in the rural part of the province (Table 1). The gender distribution of the population is equal, $50 \%$ of men, $50 \%$ of women, similar with Turkey (Table 2). 
Tourism Development in Mountainous Regions, Social Structure's Point of View;

Advantages and Disadvantages, Erzurum/Turkey Case Area

Table 1. Urban and rural census distribution of Erzurum province

\begin{tabular}{|l|r|r|r|r|r|r|r|r|}
\hline & \multicolumn{1}{|c|}{ Total } & $\begin{array}{c}\% \\
\operatorname{Tr}^{*}\end{array}$ & Urban & $\begin{array}{c}\% \\
\operatorname{Tr}\end{array}$ & $\begin{array}{c}\% \\
\text { In } \\
\text { province }\end{array}$ & \multicolumn{1}{c|}{ Rural } & $\begin{array}{c}\% \\
\operatorname{Tr}\end{array}$ & $\begin{array}{c}\% \\
\text { In } \\
\text { province }\end{array}$ \\
\hline Erzurum & 784941 & 1,11 & 485563 & 0,98 & 61,86 & 299378 & 1,44 & 38,14 \\
\hline Türkiye & 70586256 & & 49747859 & & 70,48 & 20838397 & & 29,52 \\
\hline
\end{tabular}

* Percentage in Türkiye (TUIK, 2007)

Table 2. Gender distribution of Erzurum

\begin{tabular}{|l|r|r|r|r|r|}
\hline & \multicolumn{1}{|c|}{ Total } & \multicolumn{1}{c|}{ Men } & \multicolumn{1}{c|}{$\%$} & \multicolumn{1}{c|}{ Women } & \multicolumn{1}{c|}{$\%$} \\
\hline Erzurum & 784941 & 393589 & 50 & 391352 & 50 \\
\hline Türkiye & 70586256 & 35376533 & 50 & 35209723 & 50 \\
\hline
\end{tabular}

(TUİK, 2007)

After this brief introduction of Erzurum, in the next section, the social indicators of sustainable tourism which was chosen as measurable for the case area will be detailed and the results will be given.

\section{Selected Social Indicators of Sustainable Tourism for the Case Area}

The set of indicators were determined with respect to their subject matters and measurability parameters for the case study area. After deciding the weight factors, measurements were made for Erzurum province. Some of the indicators were measured with the data obtained from responsible institutions, governmental and non governmental organizations, academic sources and researches etc., but some of them could not be measured due to the lack of suitable input data sets. In such situations, the needed data were collected by the questionnaire as mentioned above.

The questionnaire was applied both to the local hotels having "tourism operation license" and "municipality registration". The aim of the questionnaire was to determine the tourism infrastructure and measuring the added value of tourism on economical structure. The questionnaire has 17 questions focusing on analysis of physical conditions and physical capacity of the accommodation units, social structure of the workers and operating approaches of the enterprises. The sampling of the questionnaire was applied $100 \%$ of the case area which means all the tourism units in the provinces were included in the study and the results obtained were evaluated with multi-criteria decision-making method (Gürer, 2009).

This paper focuses on the social indicators (Table 3) of sustainable tourism like social structure of the employees who are working for the touristic enterprises, cultural and historical environments, sites and their diversity, quality and attraction capacities. Methodologically, after a brief description of the indicator, the measurement way is explained and the results are given.

Table 3. Selected social indicators of sustainable tourism

\begin{tabular}{|l|l|}
\hline IS1.43 & $\begin{array}{l}\text { Social effects of tourism on employment } \\
\text { (Existence of educated labor force in tourism sector) }\end{array}$ \\
\hline IS1.44 & Women employment in tourism sector \\
\hline IS10.62 & Number of cultural environments, diversity and quality of them \\
\hline IE8.125 & Attraction capacity and fame of sites and activities \\
\hline IS10.63 & Information on local culture and conservation of intangible cultural heritage \\
\hline IS8.75 & Economic and human losses related to natural disasters \\
\hline
\end{tabular}




\section{Indicator 1. Education level of labor force in tourism sector}

Education level is an important indicator among the social indicators of tourism. Employing the high level educated employees in the sector will create opportunities which help to protect and evaluate the potentials and sustainable development.

For measuring this indicator, the distribution of men and women employees in the sector and their positions are tried to define. The aim is to create equal positions both men and women employees with the same and high education level.

\section{Evaluation for Erzurum Province}

The number of educated employees in the enterprises is important in the tourism sector. The subject of qualified staff existence must be studied because it creates opportunities for tourism development. This is why we tried to analyze the education level of the staff which works for touristic enterprises.

In all accommodation units the total number of employees is 603 people in Erzurum case study area. 94 people of them are working as administrative staff, 509 are working as service staff. When the educational level is analyzed for the tourism sector, the questionnaires show that $63 \%$ of the staff is graduated from high school in Erzurum. Although in administrative status 52\% of the staff is university graduated, in service status in the fist place secondary school graduated staff is exists with $70 \%$ (Table 4) (Gürer, 2009).

Table 4. Education level of labor force in tourism sector

\begin{tabular}{|l|c|c|c|c|c|c|c|c|}
\hline Erzurum & $\begin{array}{c}\text { Women } \\
\text { (number) }\end{array}$ & $\begin{array}{c}\text { Men } \\
\text { (number) }\end{array}$ & Total & $\%$ & $\begin{array}{c}\text { Administrative } \\
\text { Status }\end{array}$ & $\begin{array}{c}\text { Service } \\
\text { Status }\end{array}$ & $\%$ \\
\hline University Educated & 20 & 33 & 53 & 9 & 49 & 52 & 4 & 0,8 \\
\hline $\begin{array}{l}\text { Vocational School of } \\
\text { Tourism Graduated }\end{array}$ & 2 & 27 & 29 & 5 & 19 & 20 & 10 & 0,2 \\
\hline $\begin{array}{l}\text { Vocational High School of } \\
\text { Tourism Graduated }\end{array}$ & - & 20 & 20 & 3 & 1 & 1 & 19 & 4 \\
\hline High School Graduated & 13 & 366 & 379 & 63 & 24 & 26 & 355 & 70 \\
\hline $\begin{array}{l}\text { Secondary School } \\
\text { Graduated }\end{array}$ & 3 & 65 & 68 & 11 & 1 & 1 & 68 & 14 \\
\hline Primary School Graduated & 4 & 50 & 54 & 9 & - & - & 53 & 11 \\
\hline Total & 42 & 561 & 603 & 100 & 94 & 100 & 509 & 100 \\
\hline
\end{tabular}

(Gürer, 2009)

When the educational status analyzed according to gender, in tourism operation licensed hotels, female employees are working as administrative staff largely, and $84 \%$ of them are university graduated. Male staff is just $45 \%$ in the same status. In service staff category, majority for the women is high school graduated with $59 \%$ and for men $72 \%$ for the same education level. In municipality registration certificated hotels, there is just one woman working as administrative staff and she is high school graduated. In these hotels, men employees that work in administrative status are high school educated in majority with $72 \%$. Among the service staff, majority is high school educated men, its percentage is 47 (Table 5) (Gürer, 2009).

According the results of questionnaires, the employees who are working in tourism operation licensed hotels are more qualified than employees of municipality registration certificated hotels. If a similar evaluation evolved for gender distribution of employees, it is possible to say women employees are more educated than men in tourism operation licensed hotels. In municipality registration certificated hotels women staff is not preferred too much and they are less educated according to men employees. 
Tourism Development in Mountainous Regions, Social Structure's Point of View;

Advantages and Disadvantages, Erzurum/Turkey Case Area

Table 5. Educational status of employees according to license types of accommodation units

\begin{tabular}{|c|c|c|c|c|c|c|c|c|c|c|}
\hline \multirow[t]{3}{*}{ Erzurum } & \multicolumn{4}{|c|}{ Tourism Operation Licensed } & \multicolumn{4}{|c|}{$\begin{array}{c}\text { Municipality Registration } \\
\text { Certificated }\end{array}$} & \multicolumn{2}{|c|}{ Total } \\
\hline & \multicolumn{2}{|c|}{ Administrative } & \multicolumn{2}{|c|}{ Service staff } & \multicolumn{2}{|c|}{ Administrative } & \multicolumn{2}{|c|}{ Service staff } & \multirow{2}{*}{ Women } & \multirow{2}{*}{ Men } \\
\hline & Women & Men & Women & Men & Women & Men & Women & Men & & \\
\hline University Educated & 20 & 25 & - & 4 & - & 4 & - & - & & \\
\hline$\%$ & 84 & 45 & - & 1 & - & 31 & - & - & 20 & 33 \\
\hline $\begin{array}{l}\text { Vocational School of } \\
\text { Tourism Graduated }\end{array}$ & 2 & 17 & - & 10 & - & - & - & - & 2 & 27 \\
\hline$\%$ & 8 & 30 & - & 2 & - & - & - & - & & \\
\hline $\begin{array}{l}\text { Vocational High School of } \\
\text { Tourism Graduated }\end{array}$ & - & 1 & - & 19 & - & - & - & - & - & 20 \\
\hline$\%$ & - & 2 & - & 4 & - & - & - & - & & \\
\hline High School Graduated & 2 & 13 & 10 & 330 & 1 & 8 & - & 15 & & \\
\hline$\%$ & 8 & 23 & 59 & 72 & 100 & 62 & - & 47 & 13 & 366 \\
\hline Secondary School Graduated & - & - & 3 & 59 & - & - & - & 6 & & \\
\hline$\%$ & - & - & 18 & 13 & - & - & - & 19 & 3 & 65 \\
\hline Primary School Graduated & - & - & 4 & 38 & - & 1 & - & 11 & & 50 \\
\hline$\%$ & - & - & 23 & 8 & - & 7 & & 34 & 4 & 50 \\
\hline Total & 24 & 56 & 17 & 460 & 1 & 13 & - & 32 & 42 & 561 \\
\hline
\end{tabular}

(Gürer, 2009)

\section{Indicator 2. Cultural Diversity}

This indicator shows the level of conservation of cultural sites, defines their advantages and diversity. This is also a basic step for creating a data bank. Heritage is not just a tool for tourism; it is also a part of cultural identity of the society. It acts as a connectivity and creation of awareness of cultural identity.

For measuring this indicator, the cultural environments are detailed with number of cultural properties and their diversity.

\section{Evaluation for Erzurum Province}

Cultural values and civil architectural heritage samples are too limited in this area while compared with Türkiye, but Erzurum city is rich enough for tourism development according to other cities in the region (Table 6).

Table 6. Types of cultural properties and their numbers

\begin{tabular}{|l|r|r|}
\hline & Erzurum & \multicolumn{1}{|c|}{ Türkiye } \\
\hline Mosque & 73 & 3819 \\
\hline Tomb & 12 & 1291 \\
\hline Cupola & 7 & 80 \\
\hline Castle & 30 & 670 \\
\hline Church & 14 & 995 \\
\hline Grave & 26 & 2718 \\
\hline Turkish Bath & 18 & 1012 \\
\hline Khan & 3 & 576 \\
\hline Fountain & 35 & 3111 \\
\hline Bridge & 23 & 1132 \\
\hline Madrasah & 7 & 234 \\
\hline War cemetery & 13 & 215 \\
\hline Door & 2 & 22 \\
\hline Bastion & 24 & 68 \\
\hline Tumulus & 17 & 2566 \\
\hline Waterfall & 1 & 25 \\
\hline Residential unit (Civil architectural sample) & 31 & 42471 \\
\hline Administrative buildings (Civil architectural sample) & 29 & 2103 \\
\hline Total & 365 & 63108 \\
\hline
\end{tabular}

(Kültür Varlıkları ve Müzeler Genel Müdürlüğü, 2009) 
Indicator 3. Existence of historical structure and architectural heritage

This indicator shows the usage of local architecture and local materials, and it measures the sustainability of local architectural characteristics and techniques and level of usage of local materials. The harmony of local architecture with the usage of local materials in the construction of touristic enterprises is an important indicator. The measurement method of this indicator is to define the usage percentage of local materials in the construction process for local architecture.

\section{Evaluation for Erzurum Province}

In field study, it was observed that, no traditional construction material was used in buildings of touristic purpose.

\section{Indicator 4. Attraction capacity and fame of the sites}

This indicator uses for defining the level of attraction capacity and the fame of sites. The target of this indicator is determining that how does sense the touristic destinations by tourists. The factors which are added values to touristic destinations are originality, hospitality and high quality management. The values of these areas depend on the conservation studies, the conservation level of the area and existence of attractive components.

This indicator can be measured with the number of sites which make the area more famous.

\section{Evaluation for Erzurum Province}

In Erzurum region there are 35 sites; most of them are archeological sites (Table 7). There are also natural sites, urban sites, historical and mixed sites. Compared to Turkey, in case study area less number of urban, historical and mixed sites exists.

Table 7. The number of sites according to their types
\begin{tabular}{|l|c|c|}
\hline $\begin{array}{l}\text { Type of Site } \\
\text { Sit Alanı Türü }\end{array}$ & Erzurum & Türkiye \\
\hline Natural Sites & 4 & 1166 \\
\hline Archeological Sites & 28 & 7766 \\
\hline Historical Sites & 1 & 142 \\
\hline Urban Sites & 1 & 220 \\
\hline Mixed Sites & 1 & 428 \\
\hline Total & 35 & 9722 \\
\hline
\end{tabular}
(Kültür Varlıkları ve Müzeler Genel Müdürlügü, 2009)

\section{Indicator 5. Increasing the integration of women labor force to tourism sector}

This indicator was evaluated for measuring the ratio / percentage of women labor force and defining their working conditions in tourism sector. It measures with the accessing capacity of women to job opportunities, and its percentage (across/converse/contrary $100 \mathrm{men}$ ). The results of this indicator have the percentage of the integration ratios of women and men labor forces.

During the evaluation process of this indicator, gender distribution of the employees and their working status in the accommodation units were taking into consideration.

\section{Evaluation for Erzurum Province}

The number of employees is also analyzed according to the type of licenses of accommodation units. In Erzurum, the gender distribution of the employees which are working in the hotels that have tourism operation licensed, $7 \%$ is women and $93 \%$ is men employees. In municipality registration certificated hotels, $2 \%$ of employees are women and $98 \%$ are men (Table 8 ). 
Tourism Development in Mountainous Regions, Social Structure's Point of View;

Advantages and Disadvantages, Erzurum/Turkey Case Area

Table 8. Distribution of employees according to type of entrepreneur

\begin{tabular}{|c|c|c|c|c|c|c|}
\hline \multicolumn{7}{|l|}{ Erzurum } \\
\hline & \multicolumn{2}{|c|}{ Tourism operation licensed } & \multicolumn{2}{|c|}{ Municipality registration } & \multicolumn{2}{|c|}{ Total } \\
\hline & $\begin{array}{c}\text { Sayı } \\
\text { Number }\end{array}$ & $\%$ & $\begin{array}{c}\text { Sayı } \\
\text { Number }\end{array}$ & $\%$ & $\begin{array}{c}\text { Sayı } \\
\text { Number }\end{array}$ & $\%$ \\
\hline Women & 41 & 7 & 1 & 2 & 42 & 7 \\
\hline Men & 516 & 93 & 45 & 98 & 516 & 93 \\
\hline Total & 557 & 100 & 46 & 100 & 603 & 100 \\
\hline
\end{tabular}

(Field study, 2007)

In tourism operation licensed hotels, $59 \%$ of women employees work in administrative status and $41 \%$ in service status. $11 \%$ of men employees are working in administrative status and $89 \%$ are working as service staff. In municipality registration certificated hotels, all women employees are working in administrative status, and $29 \%$ of men employees in administrative status and $71 \%$ of them are working in service staff (Table 9).

Table 9. Distribution of employees according to license type of accommodation units

\begin{tabular}{|l|c|c|c|c|c|c|c|c|}
\hline Erzurum & \multicolumn{4}{|c|}{ Tourism operation licensed } & \multicolumn{4}{c|}{ Municipality registration } \\
\cline { 2 - 10 } & \multicolumn{2}{|c|}{ Women } & \multicolumn{2}{c|}{ Men } & \multicolumn{2}{c|}{ Women } & \multicolumn{3}{c|}{ Men } \\
\hline & Number & $\%$ & Number & $\%$ & Number & $\%$ & Number & $\%$ \\
\hline Administrative & 24 & 59 & 56 & 11 & 1 & 100 & 13 & 29 \\
\hline Service & 17 & 41 & 460 & 89 & - & - & 32 & 71 \\
\hline Total & 41 & 100 & 516 & 100 & 1 & 100 & 45 & 100 \\
\hline
\end{tabular}

(Gürer, 2009)

The distribution of women employees in tourism sector is an important indicator. The integration level of women staff to tourism sector is one of the key subjects for local development. In case area, the majority of the staff is consisting of men workers. In Erzurum, women employees are hiring especially in tourism operation licensed hotels.

In Erzurum, women employees are working in the hotels which are located in Palandöken Mount densely. This result also accept as an indicator which shows tourist profile is an important factor on gender distribution of the staff in accommodation units. Besides, the capacity of the hotels and their occupancy rate has a direct impact on the number of staff. In Erzurum, a significant part of employees which are working at tourism operation licensed hotels are in Palandöken mountain region.

Erzurum has a strict and close up socio cultural structure. Specially in the hotels that are located in the city center, the existence of little or no women employees can be accept as a reflection of social structure of the city. As a result, except mountain hotels, the number of women employees in all accommodation units is unsatisfactory.

Indicator 6. Assessing the advanced health services

One of the social indicators of sustainable tourism can be accept as the level of health services. In developing countries, especially in tourism regions, the level of health services is a prior criterion for choosing the destination. This is why this indicator selected separately and taking into consideration.

The measurement method of this indicator is to define general hospital opportunities, existence of specialists and educated health staffs, physical capacities etc.

\section{Evaluation for Erzurum Province}

For measuring the level of health services provided the number of hospitals in the case study area, number of beds, specialists (doctor) and health staff per person are handled as criteria. According 
to these criteria, Erzurum is found to be the most developed province in the region. There are totally 25 hospitals in the region, 14 of them are in Erzurum, one private hospital is included. Thus, the bed capacity, number of specialist and the number of health staff in the province is higher than the others in the region (Table 10).

Table 10. Basic indicators of health services and health staff

\begin{tabular}{|l|c|}
\hline & Erzurum \\
\hline Number of Hospitals (Public/ Government) & 13 \\
\hline Number of Hospitals (Private) & 1 \\
\hline Total & 14 \\
\hline Number of beds (Public /Government) & 3055 \\
\hline Number of Beds (Private) & 45 \\
\hline Total & 3100 \\
\hline Number of person per bed & 253 \\
\hline Number of specialist & 390 \\
\hline Total number of specialist & 1094 \\
\hline Number of person per specialist & 717,5 \\
\hline Number of Dentist & 76 \\
\hline Number of Pharmacist & 117 \\
\hline Total number of health staff & 1287 \\
\hline Number of person per health staff & 609,8 \\
\hline
\end{tabular}

(TUIK; 2007)

Erzurum province has the most advantages situation in the region. It also serves as the area headquarters in the region. This makes the province more preferable both for the local people and for tourists.

\section{Indicator 7. Existence of specialists in the sectors related with tourism}

This indicator defines the effects of tourism development on general situation of employees. This indicator can be measured by season dependency, hometown of workers and their income levels.

\section{Evaluation for Erzurum Province}

In Erzurum, $65 \%$ of all employees are working as permanent, $35 \%$ is seasonal (Table 11). In tourism operation licensed hotels, $65 \%$ of all employees are working as fulltime, $35 \%$ is part time. In municipality registration certificated hotels $91 \%$ of workers are in fulltime status, whereas $9 \%$ in part time (in season only) status (Table 11).

Table 11. Seasonal and permanent employee's status of tourism operation licensed and municipality registration hotels.

\begin{tabular}{|c|c|c|c|c|}
\hline \multicolumn{5}{|c|}{ Tourism operation licensed } \\
\hline & \multirow{2}{*}{ Administrative } & \multirow{2}{*}{ Service } & \multicolumn{2}{|c|}{ Total } \\
\hline & & & Number & $\%$ \\
\hline \multicolumn{5}{|l|}{ Erzurum } \\
\hline Permanent & 57 & 307 & 364 & 65 \\
\hline Seasonal & 23 & 170 & 193 & 35 \\
\hline Total & 80 & 477 & \multirow[t]{2}{*}{557} & 100 \\
\hline \multicolumn{4}{|c|}{ Municipality registration } & \\
\hline & \multirow{2}{*}{ Administrative } & \multirow{2}{*}{ Service } & \multicolumn{2}{|c|}{ Total } \\
\hline & & & Number & $\%$ \\
\hline \multicolumn{5}{|l|}{ Erzurum } \\
\hline Permanent & 13 & 29 & 42 & 91 \\
\hline Seasonal & 1 & 3 & 4 & 9 \\
\hline Total & 14 & 32 & 46 & 100 \\
\hline
\end{tabular}

(Gürer, 2009) 
Tourism Development in Mountainous Regions, Social Structure's Point of View;

Advantages and Disadvantages, Erzurum/Turkey Case Area

This indicator shows, with the data getting from the questionnaire, the number of seasonal staff is directly related with the bed capacities of the accommodation units. In Erzurum, especially the hotels at the Palandöken Mount, has more customers in winter season, and these hotels need extra staff in this season for more qualified serving. The statue of seasonal staff is important because it creates additional employment.

\section{Conclusion and Recommendations}

The sustainability of social issues in mountainous regions is an important subject because of relatively low development level of them. But in this process, each indicator that handled has to be analyzed with both its advantages and disadvantages. In this extent possible advantages and disadvantages of each indicator can be listed as follow;

\section{Indicator 1. Education level of labor force in tourism sector}

Advantages

- Improving service quality makes the region more preferable by tourists

- Improving customer satisfaction

- Contribution to sustainability of resources with more conscious consumption

- More effective promotion of the region

Disadvantages

- The migration demand of educated labor force to developed regions

Indicator 2. Number of cultural environments, diversity and quality of them

Advantages

- Existence of cultural areas create diversity and contributes to development with tourism Disadvantages

- Densely use of sensitive areas makes the sustainability more difficult

Indicator 3. Existence of historical structure and architectural heritage

Advantages

- $\quad$ Creates richness for tourism

Disadvantages

- Limits the new construction opportunities in the heritage areas

Indicator 4. Attraction capacity and fame of sites and activities

Advantages

- More effective promotion of the region

- Increases the number of visitors

Disadvantages

- Increased number of visitors makes more pressure on the sites and natural recourses, and this creates difficulties in conservation

Indicator 5. Women employment in tourism sector

Advantages

- Improves the quality of services

- Creates their economic independency for women

- Strengthening the social position of women 


\section{Disadvantages}

- The migration demand of educated labor force to developed regions

Indicator 6. Assessing the advanced health services

Advantages

- Improves quality of life

- Makes the region more preferable for tourists

Disadvantages

- Creates possibility of decreasing service quality

- Makes the sustainability more difficult

Indicator 7. Existence of specialists in the sectors related with tourism

Advantages

- Contributes the development with tourism

Disadvantages

(It couldn't define any disadvantages for this indicator).

Finally, it is possible to say, the social structure of the society and the tourism labor force is important for the sustainability of the natural, cultural and historical values. And it is also important for the development of tourism sector. The quality of services and the promotional activities that belong to social structure makes the area more attractive and more preferable. The diversification of local values and conservation level of the area and the quality of services are the first decision making parameters for the tourists. If an area improves the advantages and eradicates disadvantages, sustainable tourism development will be more easily. 


\section{Tourism Development in Mountainous Regions, Social Structure's Point of View; Advantages and Disadvantages, Erzurum/Turkey Case Area}

\section{References}

Briquel, V. 2006. “Key Issues of Alpine Development”, Diamont, April 2006, 1-4.

Dax, T. 2002. "Research on mountain development in Europe: Overview of Issues and priorities", The Innovative Structures for The Sustainable Development of Mountainous Areas Conference, Thessaloniki, 1-2.

Denniston, D. 1996. "People and The Planet: People and Mountains", Pinnacles of Diversity, Planet 21, London. 5 (1) 1-4.

Euromontana. 2004. "Unlocking the mountains - a new approach to rural development for Europe's mountains", The Forth European Mountain Convention, France, 5.

Funnell, D. and Parish, R. 2001. "Mountain Environments and Communities", Routledge, NY, 3-8, 260-264.

Gürer, N. 2009. "The Contribution of Tourism to The Development of Mountainous Regions, Case Study: Erzurum Erzincan Bayburt Region of Turkey", Gazi University, Institute of Science and Technology, Department of City and Regional Planning, Ankara (Unpublished PhD Thesis).

Gürer, N. 2010. "The Tourism Potentials of Mountain Regions and The Insufficiency of Valuing Them", Global Change and the World's Mountains Conference, 26-30 September 2010, Perth, Scotland, UK.

Heberlein, T.A., Fredman, P. and Vuorio, T. 2002. "Current Tourism Patterns in The Swedish Mountain Region", Mountain Research and Development, 22 (2) 142-149.

Ives, J.D. 1992. “The State of The World Mountains”, London Zed Books, London, xiii-xv.

Kruk, E., Hummel, J. and Banskota K. 2007. "Facilitating Sustainable Mountain Tourism; Volume I - Resource Book", ICIMOD, Nepal, 26, 30-34, 83-90.

Kültür ve Turizm Bakanlığı, Kültür Varlıkları ve Müzeler Genel Müdürlüğü. 2009. Taşınmaz Külttür ve Tabiat Varlıkları Envanter Sistemi.

Messerli, B. and Ives, J.D. 1997. "Mountains of the World: a Global Priority”, London, Parthenon, 1-2.

Mountain Agenda. 1997. "Mountains of The World, Challenges for The 21st Century”, Mountain Agenda, Switzerland, 2-3.

Mountain Institute. 1999. "Mountains: A Global Resource", A special supplement to Social Education, U.S. Agency for International Development, 282-296.

Nepal, S. 2002. "Mountain Ecotourism and Sustainable Development: Ecology, Economics and Ethics", Mountain Research and Development, 22 (2) 104-109.

Pickering C.M., Harrington, J. and Worboys, G. 2003. "Environmental Impacts of Tourism on the Australian Alps Protected Areas: Judgments of Protected Area Managers", Mountain Research and Development, 23 (3): 247-254.

Price, M. 2002. "Mountains: Globally Important Ecosystems”, Moving Mountains, FAO Unasylva, No. 195, 2-8.

Price, M., Jansky, L. and Iatsenia, A. 2004. "Key Issues For Mountain Areas", United Nations University Press, USA, 1-10, 38-57, 87-94, 111-118.

Price, M. and Kim, E. 1999. "Priorities For Sustainable Mountain Development in Europe, International Journal of Sustainable Development \& World Ecology, 6: 203-219.

Rogerson, C.M. 2002. "Tourism and Local Economic Development: The Case of The Highlands Meander", Development Southern Africa, 19 (1) 144-167.

Somuncu, M. and İnci, A. 2004. "Balancing Protection and Utilization in Overcoming Inaccessibility: A rural development model in a mountainous area of Turkey”, Mountain Research and Development, 24 (4): 307-311.

TUİK. 2007.“Adrese Dayalı Nüfus Kayıt Sistemi Nüfus Sayımı”, Türkiye İstatistik Kurumu, Ankara, 14, 31. 